\title{
UMA PERSPECTIVA PARA ACOMPANHAR O PROCESSO DOS BEBÊS DE CONQUISTA DA AUTONOMIA NA CRECHE
}

\author{
Angela Scalabrin Coutinho ${ }^{\mathrm{i}}$ \\ Daniele Marques Vieira ${ }^{\text {ii }}$
}

\begin{abstract}
Resumo: Este artigo tem por objetivo apresentar elementos para a compreensão da autonomia dos bebês no contexto educativo da creche. Seleciona sequências narrativas que envolvem de modo destacado um bebê e que representam aspectos de seu processo de conquista da movimentação que permitem refletir acerca da autonomia, do movimento e das relações com outros sujeitos, e sua inter-relação no processo de desenvolvimento. A partir da análise das sequências narrativas, destaca que a proposição por parte dos adultos de um entorno óptimo é condição para a conquista da autonomia dos bebês, contudo a ação dos bebês deve ser sempre tomada como referência e compreendida como singular.
\end{abstract}

Palavras-chave: Autonomia; Bebê; Movimento; Creche; Narrativas Visuais.

\section{A PERSPECTIVE TO FOLLOW THE BABY'S PROCESS OF CONQUEST OF THE AUTONOMY IN THE NURSERY}

\begin{abstract}
This article aims to present elements for understanding the autonomy of babies in the educational context of nursery. Select narratives sequences that involve the highlighted view in an infant and represent the aspects of its movement conquest process that show reflection on autonomy, movement, and relationships with other individuals, and their interrelationship in the process of development. From the analysis of narrative sequences, highlights that a proposal by adults of an ideal type is the condition for achieving autonomy of babies, which is not an action of babies that should always be performed as a reference and understood as singular.
\end{abstract}

Keywords: Autonomy; Baby; Movement; Nursery; Visual Narratives.

\section{INTRODUÇÃO}

Este texto emerge de um estudo desenvolvido sobre as ações sociais dos bebês e o processo de constituição da docência a partir da compreensão dessas ações. Propicia reflexões tendo como base a documentação pedagógica com ênfase nas narrativas visuais produzidas por sequências de fotografias, as quais permitem acompanhar gestos, expressões e perscrutar a ação

2020 Bargas; Ayoub; Assaritti, Scarazzatto, Assis. Este é um artigo de acesso aberto distribuído sob os termos da Licença Creative Commons Atribuição Não ComercialCompartilha Igual (CC BY-NC-4.0), que permite uso, distribuição e reprodução para fins não comerciais, com a citação dos autores e da fonte original e sob a mesma licença 
do bebê, um convite à interpretação e ao estabelecimento de relações que confrontam o vivido para além da imagem, contudo, acionado por ela.

No processo de análise das narrativas visuais, as ações observadas nas sequências em momentos diferentes do cotidiano bem como o seu entorno permitem relacionar a organização do espaço, as condições à interação dos bebês e a conquista de sua autonomia. Entre outros aspectos, a análise revela como no contexto investigado a autonomia se potencializa mediante um olhar sensível e intencional, aprimorado por focalizar as demandas exteriorizadas, o que contribui para pensar a própria prática educativa na creche.

A partir da inquietação que emergiu nessa investigação, nos propomos apresentar elementos para a compreensão da autonomia dos bebês no contexto educativo da creche ${ }^{3}$, tomando como base o estudo do processo de conquista da autonomia vivenciada por uma bebê. A escolha da investigação como estudo de caso, se ancora no necessário exercício de dar visibilidade às experiências singulares dos bebês em um contexto de convívio coletivo, no sentido de refletir sobre como favorecer as relações sociais sem prescindir do conhecimento das experiências singulares dos bebês. Configura também uma possibilidade pertinente para problematizar a prática educativa em processos formativos, uma vez que permite focalizar o bebê em suas interações, enaltecer aspectos que se evidenciam quando podemos olhá-los detidamente, o que se mostra propício com o uso da fotografia ${ }^{4}$. Sendo assim, selecionamos sequências narrativas que representam aspectos de um processo de conquista da movimentação e permitem refletir acerca da autonomia, do movimento e das relações com outros sujeitos, bem como sua inter-relação no processo de desenvolvimento.

O texto está organizado em cinco seções. A introdução é seguida de uma seção que problematiza o lugar dos bebês nos novos estudos sociais da infância, no sentido de destacar a importância de produções que se situem nesse campo e expandam a concepção de criança para os sujeitos de pouca idade que se lançam na experiência de tornarem-se crianças. A seção seguinte aborda os conceitos de autonomia e heteronomia, buscando situar o debate de modo mais amplo e abrir a discussão para a seção seguinte que tratará da concepção de autonomia relacionando-a aos bebês e às práticas pedagógicas que os tomam como sujeitos competentes, que agem no mundo a partir da proposição intencional por parte dos adultos de um entorno óptimo (GODALL, 2016). Por fim, as considerações finais, em que destacamos a concepção de autonomia que abordamos ao longo do artigo. 


\section{QUAL O LUGAR DOS BEBÊS NO CAMPO DOS NOVOS ESTUDOS SOCIAIS DA INFÂNCIA?}

A pergunta que abre essa seção posiciona uma reflexão sobre qual lugar o bebê ocupa na agenda de pesquisa dos novos estudos sociais. Nesse sentido, destaca que embora esse campo seja pioneiro na problematização da marginalidade das crianças à produção do conhecimento em campos como o sociológico, a compreensão de quem é a criança, referenciada a partir de uma dada idade, nem os novos estudos sociais da infância conseguiram incluir, de modo proeminente, os bebês.

Tal constatação é decorrente de um levantamento realizado em 2008, da produção identificada como vinculada a esse campo em língua portuguesa, francesa e italiana (COUTINHO, 2010), localizando apenas dois trabalhos, até aquele momento, que se situavam no campo e estudavam os bebês, um em língua portuguesa e outro em língua francesa, e do estudo de Gonçalves (2014) que analisou os estudos sobre bebês no campo da Pedagogia da Infância e constatou que na restrita produção identificada a maioria se situava na área da Psicologia, revelando uma determinada perspectiva sobre o bebê.

A predominância da psicologia no estudo dos bebês é reconhecida, o estudo francês identificado no levantamento é uma extensa análise da concepção de bebê no pós segunda guerra mundial na França, realizada pelo sociólogo Gerald Neyrand (2000). Para o pesquisador a lógica da família contemporânea é psicológica. Ele cita os programas de rádio, as revistas especializadas e um conjunto de aparatos que surgem nesse período, com forte influência da psicanálise, para a compreensão dos processos de desenvolvimento e, consequentemente, da educação das crianças, o que incide diretamente na constituição da maternidade, da paternidade e no papel das instituições coletivas de educação e cuidado.

No Brasil a contribuição do campo da psicologia também é destacada, Rocha (1999) ao analisar a produção sobre a educação infantil entre os anos de 1990 e 1996, identifica uma forte presença da psicologia e uma abertura mais recente para outras áreas, como história, sociologia, antropologia. Destacamos aqui a atuação de um grupo de pesquisa, o Centro de Investigação sobre o Desenvolvimento e Educação (CINDEDI), vinculado à Faculdade de Filosofia, Ciências e Letras de Ribeirão Preto da Universidade de São Paulo e liderado, por muito tempo, por Maria Clotilde Rosseti-Ferreira, importante pesquisadora da área. Desde 1979 o CINDEDI vem se constituindo como importante espaço de estudo das crianças e da sua educação e reserva ao estudo dos bebês um lugar central. 
Tal menção tem um duplo objetivo a fim de abordarmos a complexidade que envolve o estudo de bebês. Em primeiro lugar reconhecer que muito do que se tem produzido no Brasil sobre e com os bebês é decorrente da importante atuação desse grupo, que tratou de temas centrais para a educação dos bebês, como o papel da interação com os pares para o desenvolvimento dos bebês e o seu processo de adaptação à creche, lançando mão de instrumentos metodológicos que se mostram fundamentais ao estudo com crianças, principalmente o uso do vídeo. Outro objetivo é problematizar que ao tecer a crítica à visão normativa de criança advinda de campos como a psicologia e a sociologia, o que está na base são determinadas perspectivas, que tiveram - e têm - grande influência nas concepções de criança, desde bebês, e de infância, as quais orientam as práticas educativas, e isso não significa descartar toda e qualquer produção advinda desses campos - principalmente da psicologia, tida como a grande vilã da visão universalista de infância - pelo contrário, esses campos possuem importantes contribuições e cabe uma análise crítica e aberta no sentido de identificar com quais perspectivas faz sentido estabelecer um diálogo.

Assim, ainda que escassos, os estudos com bebês no campo dos novos estudos da infância têm mantido a característica interdisciplinar do campo envolvendo principalmente áreas como educação, psicologia, filosofia e sociologia (COUTINHO, 2010; GUIMARÃES, 2011; TEBET, 2013; MATTOS, 2018), e contribuído com a compreensão dos processos de constituição dos bebês como atores sociais competentes, com destaque para categorias como as interações e a linguagem, dando centralidade ao corpo.

Tais estudos também avançam no que Alan Prout (2005) afirma ser um dos desafios da área, revelar o que constitui a ação social das crianças, para além de afirmar que elas possuem uma ação, e no caso dos bebês esse parece ser um desafio ainda maior, inclusive na perspectiva de reconhecer que a compreensão da sua agência, em muitos casos, exigirá a consideração que esse processo ocorre a partir da sua relação de interdependência com os adultos (WYNESS, 2013), ou seja, os bebês possuem competência social para se relacionarem entre eles, mas essa competência é desenvolvida na relação com todo o entorno social, o que implica a ação dos adultos.

A rigor esse não deveria ser um problema ao estudo com bebês, tendo em vista que se os adultos estão em interação com eles significa que há por parte dos adultos uma disposição para a relação, a questão é identificar como essas relações se estabelecem, no sentido, que o adulto é um importante parceiro na significação do mundo pelo bebê (BONDIOLI, 1999), mas não é o único. Essa assertiva está presente no campo dos estudos com bebês, mas ainda exige atenção no 


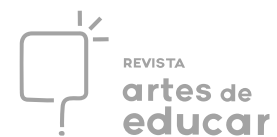

sentido de compreender que focar o olhar nos bebês e nas relações que estabelecem com seus pares, não significa abrir mão das relações que estes estabelecem com os adultos, até porque ainda que os adultos não mediem todas as relações dos bebês com o seu entorno, eles são os responsáveis por organizar o espaço e o tempo para que estas relações sejam favorecidas, assim como a agência dos bebês.

Agir socialmente implica um processo de reciprocidade, ou seja, o ator orienta [...] as suas ações a partir da expectativa em relação à determinada atitude do seu parceiro, o que trará consequências para o desenvolvimento da ação e da configuração da relação (COUTINHO, 2019, p. 52), nesse sentido, não há relação social sem reciprocidade.

Ter consciência dessa característica da ação social exige reflexão sobre dois aspectos: i) os processos de constituição humana são sociais, portanto, importa valorizar as relações entre os pares, contudo estes processos possuem marcas da singularidade de cada ator, assim é fundamental conhecer as crianças, seus repertórios, preferências, competências sociais, o que exige um olhar atento e investigativo relativamente à cada criança, para além do conhecimento das dinâmicas das relações nos espaços coletivos de educação e cuidado. Tal pressuposto têm implicações profundas nas condições de trabalho das professoras e no modo como estabelecem relação com as crianças, sendo este o segundo ponto; ii) as relações fomentadas pelas professoras em relação às crianças implicam a valorização das interações entre as crianças e o entendimento que um dos objetivos centrais da educação é a emancipação ${ }^{5}$ (GRAMSCI, 2004).

$\mathrm{Na}$ educação infantil a ideia de emancipação ainda é um desafio, sobretudo, na perspectiva dialética de Gramsci, que prevê oportunidade para todos, e de Batista (2008, p. 53), que a define como a possiblidade

[...] da vivência de direitos sociais e políticos em contraposição à condição de tutela; de uma concepção educacional que tem como princípios as crianças como sujeito de direitos sociais e políticos que produz cultura. Falar de emancipação das crianças significa dizer que a educação infantil deve se tornar um lugar de emergência da infância, de vivência intensa e plena dessa fase da vida. Significa reconhecê-la como alguém que é e não como um vir-a-ser.

Essa compreensão está traduzida como autonomia em muitos documentos que orientam as ações no âmbito das instituições e das propostas pedagógicas, tal como o projeto político pedagógico, e possui especificidades quando se trata de bebês, uma vez que se considera a autonomia implicada em um processo de conquista e não de subordinação, o que é exatamente o seu oposto. Sendo assim, o que significa falar em autonomia nos processos educativos? 


\section{O PAPEL DO ADULTO E A AUTONOMIA DOS BEBÊS: UMA PERSPECTIVA PARA PENSAR AS RELAÇÕES EDUCATIVAS NA CRECHE}

Ao partirmos da compreensão de que os bebês se constituem atores sociais, na relação com o outro - adultos, pares e crianças maiores - em intrínseca mobilização para conquistar novas condições as quais lhes possibilitem exercer autonomamente sua agência, assim, podemos pensar a reciprocidade perene no meio em que estão inseridos.

Deste modo, ao voltar-se para o modo como os bebês constroem sua autonomia nas interações e por meio das relações com o meio - material e humano -, é que se mostra relevante refletir acerca da prática educativa, em que se pese o papel do adulto na relação com os bebês. Godall (2014) destaca estudos realizados por David e Appel (2013) no Instituto Lóczy, que enfatizam em suas observações a organização da vida do bebê na instituição mediada por uma prática profissional assentada na atenção pessoal como atividade principal, revestida pela intencionalidade de favorecer a atividade autônoma do bebê, garantidas as condições de bemestar e conforto, segundo uma "preocupação por manter sempre, ou suscitar, o prazer que o bebê sente em relação à atividade que se propõe e por favorecer qualquer possibilidade de autonomia" (DAVID; APPEL, 2013, p. 37).

Dado que as atividades de atenção pessoal são cotidianas e estruturantes na instituição educativa, o modo como ocorrem se constitui em importante referência para os bebês no que tange a sua experiência social, ou seja, incidem sobremaneira enquanto repertório disponível em sua comunicação com o outro. E ainda, podemos pensar em consonância com a perspectiva pikleriana que, ao se promover condições favoráveis para os bebês realizarem por sua própria iniciativa o gesto e a movimentação que complementa a ação de cuidado, assim, se constrói uma relação cooperativa e valorativa de participação em relação a si, fomentando um modo de ser e de estar com ênfase na atividade autônoma.

Nessa direção, Godall (2016) enfatiza o papel do adulto na organização do entorno óptimo como atividade educativa central para promover condições que favoreçam a conquista da autonomia pelos bebês. Contudo, ressalva o entorno óptimo é condição indispensável, mas a própria iniciativa do bebê é a chave, o impulso dinâmico do desenvolvimento (GODALL, 2016, p. 82). Com isso, podemos pensar que a organização do espaço-ambiente enquanto entorno óptimo constitui ação educativa intencional, assim como a possibilidade de ação pelo próprio bebê mediante a atitude do adulto que, ao não determinar o gesto, mas garantir espaço e 
oportunidade ao bebê de realizar por si a ação, parece configurar-se o favorecimento à construção da sua autonomia.

Imbuídas dos princípios piklerianos em diálogo com o que os estudos da infância têm nos possibilitado problematizar e refletir acerca da responsabilidade da instituição educativa em oferecer oportunidades equânimes de acesso aos bens produzidos pela cultura e da relação entre adultos e bebês neste contexto, focalizamos o processo vivido por uma bebê desde sua entrada na creche aos 4 meses acompanhando-a até os 20 meses de vida. Tal possibilidade de estudo se fundamenta na observação da criança contextualizada para pensar as relações educativas implicadas em uma perspectiva dialógica, por meio de investigação narrativa.

Assim, a seguir delinearemos o contexto em questão, a instituição e os sujeitos envolvidos - bebês, professoras e pesquisadoras -, a fim de configurar a gama de inter-relações presentes na situação educativa em tela, referente à construção da autonomia de bebês na creche tendo como eixo a relação adulto-criança.

A instituição de educação infantil, campo desse estudo, foi escolhida por sua proposta pedagógica explicitar elementos concernentes aos princípios instituídos pelas DCNEI (BRASIL, 2009) em condições que os favorecem, tais como: o espaço físico; a quantidade de adultos por crianças e um número máximo de crianças nos grupos; a organização de pequenos grupos para vivências significativas aos processos educativos; a prática da documentação pedagógica como estratégia de acompanhamento, reflexão e planejamento. A referida instituição ${ }^{6}$, situada em um bairro de classe média-alta, de Curitiba, capital do Paraná, atende a faixa etária de 04 meses a 06 anos de idade, sendo que sua proposta pedagógica se estrutura pelos eixos Interações, Brincadeira, Arte e Natureza. Em relação ao grupo de bebês, o espaço físico se diferencia por compor à sede principal, uma casa especial para a faixa etária de 04 meses a 28 meses, denominada "Casa dos Bebês", onde além das salas de referência dos grupos, há uma varanda, uma sala de movimento (destinada especialmente a pequenos grupos com elementos de madeira e outras materialidades que convidam os bebês a exercerem sua movimentação), uma praça com refeitório, o lactário e o pátio coberto, e na área externa o Quintal “das frutas" onde há tanque de areia, balanços, módulo de madeira (adaptado à faixa etária) com rampa, mezanino e escorregador, bancos de madeira e várias frutíferas, e um Recanto - cercado.

Os grupos - turmas de referência - têm uma professora regente e duas professoras auxiliares, variando entre 10 a 12 crianças conforme a idade - de 04 meses a 12 meses; de 12 meses a 20 meses; de 16 meses a 28 meses -, sendo que o grupo de bebês menores tem no máximo 10 crianças e os grupos de crianças que já caminham no máximo 12 crianças. 


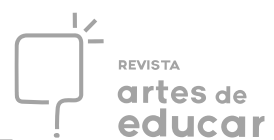

A prática educativa se organiza a partir de momentos que demarcam o cotidiano pela regularidade pertinente ao grupo, conforme as demandas e necessidades deflagradas da idade e as possibilidades interativas observadas, sendo conduzidos por rituais relativos às possibilidades observadas e manifestas pelas crianças, individual e coletivamente. Nesse sentido, a conquista da autonomia se constitui em um dos princípios do processo educativo, em que cada criança é considerada a partir da sua condição para relacionar-se no meio em que está inserida, sendo foco da prática educativa promover situações significativas aos grupos a fim de provocar cada criança em sua potencialidade.

A proposta de realizar um estudo de caso com uma bebê desde os 5 meses aos 22 meses, envolvendo o seu entorno, ou seja, a relação com seus pares, os elementos materiais presentes nos ambientes conhecidos, a relação com a pesquisadora-documentarista ${ }^{7}$ e as 07 professoras (4 em 2018 e 3 em 2019), se fundamenta na compreensão de duas dimensões intrínsecas a esse processo e que a pesquisa se atém: 1. A relacional, que consiste na percepção da condição dos sujeitos envolvidos como seres que se influenciam mutuamente; 2. A narrativa, que significa o processo como uma perspectiva do vivido a ser retratada segundo a escolha do sujeito que documenta a realidade, posto que a fotografia é recorte e escolha, indubitavelmente ancorada no olhar e repertório do fotógrafo que captura da cena algo a ser cristalizado ${ }^{8}$.

Consistiu objeto de investigação que resultou neste estudo, o processo de conquista da movimentação de Laura ${ }^{9}$ desde a sua entrada na creche - 04 meses - até a aquisição da marcha plena - 22 meses. Durante esse período, se percebeu a forte tendência de Laura pela atenção aos detalhes com maior permanência na posição deitada. A postura sentada foi sendo propiciada em momentos de alimentação, eventualmente, da música trazida semanalmente como oportunidade especial conduzida por um docente especialista, ou frente ao desejo manifesto por Laura de assim permanecer mesmo que tal postura não fosse constituída por sua própria ação, mas conduzida pelo adulto. Aos 10 meses, Laura passou a se movimentar sentada, utilizando a lateral dos pés como apoio para se deslocar, ainda que essa estratégia fosse eficiente para seu deslocamento, não the impingia agilidade, algumas vezes lhe causando frustração, o que foi sendo monitorado pelas professoras como abertura à novas possibilidades. A peculiaridade da atividade motora de Laura, suscitou da professora contemplar no espaço-ambiente, condições que considerassem o princípio do entorno óptimo, delineando aspectos significativos à situação educativa de conquista da movimentação, a saber: elementos para provocar interesse; presença do adulto como observador-mediador-interlocutor das ações interativas proeminentes; diversificação de oportunidades em relação ao posicionamento do corpo - ora deitado, ora de 
bruços - considerando a dependência do bebê em relação ao adulto para o seu deslocamento; situações de interação em espaços distintos - sala de referência, sala de movimento, quintal - e com pares - outros bebês em condições diversificadas de movimentação. Sobretudo, se intensificou no planejamento momentos de vivência da Laura na Sala de Movimento ${ }^{10}$.

A partir de momentos diferenciados das interações de Laura no contexto educativo, selecionamos sequências de narrativas que representam aspectos de seu processo de conquista da movimentação, o que nos permitiu refletir acerca da autonomia, do movimento e das relações com outros sujeitos, e sua inter-relação no processo de desenvolvimento de bebês. Para confrontar as cenas selecionadas da observação cotidiana, utilizamos como parâmetro a Escala de Desenvolvimento Infantil do Instituto Emmi Pikler para o desenvolvimento motor ${ }^{11}$ (FALK, 1997 citado por SOARES, 2017).

\section{Sequência 1: Interação com móbile}
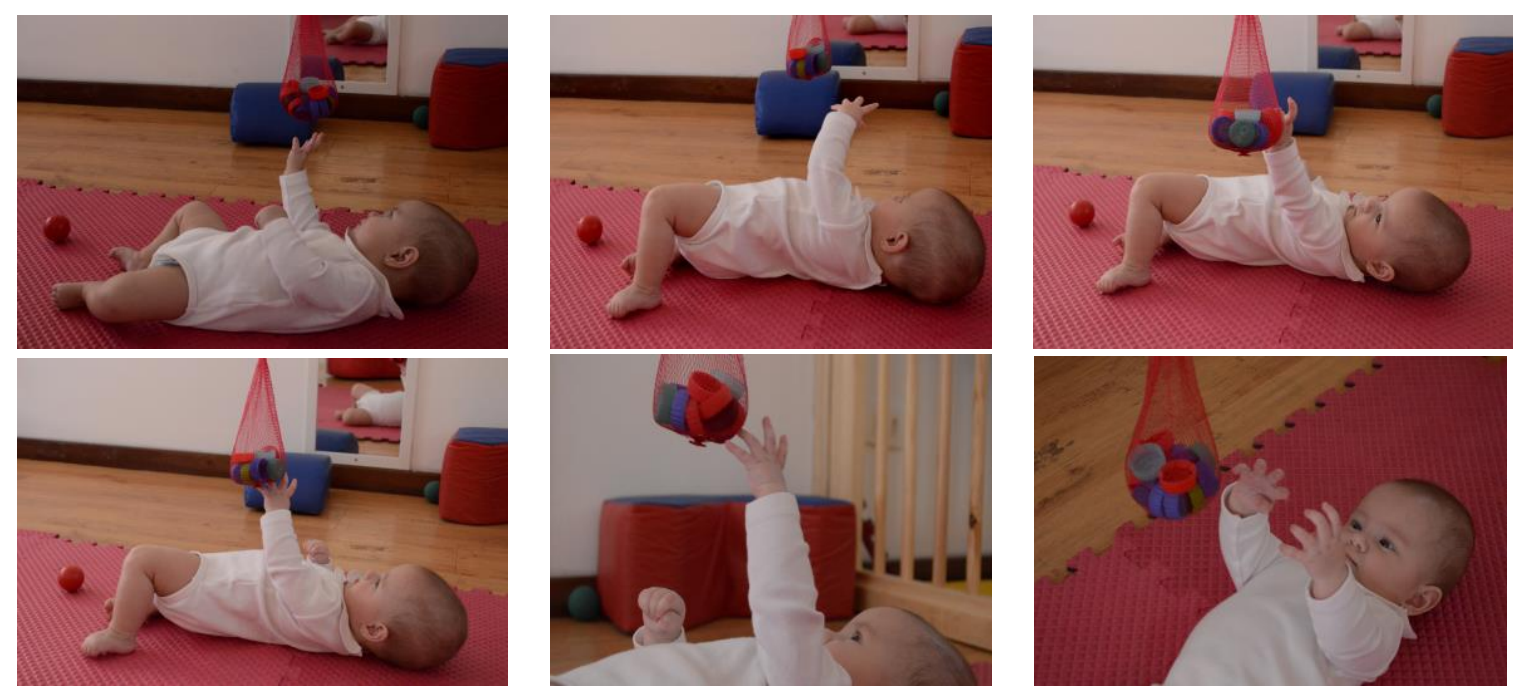

FONTE: Daniele Marques Vieira (2018)

LEGENDA: Situação de Interação, Sala da Turma, criança de 06 meses, Escola Parlenda.

Aos seis meses, Laura vira parcialmente de lado - como podemos ver na Sequência 1 posicionando o pé com o joelho dobrado e deslocando o ombro para alcançar o objeto suspenso, tendo em vista o objetivo de alcançar o objeto sua estratégia parece corresponder ao desejo que a mobiliza. Neste caso, o móbile preso ao teto da sala e disponível ao bebê em uma altura que lhe permitisse acessar a materialidade, consiste em desafio possível a ser alcançado, provocando sua movimentação - posicionamento de pernas, dorso, mãos e braços. Segundo os parâmetros piklerianos, a postura virar de lado pode ser observada entre bebês de 3 a 7 meses, por iniciativa própria e sem ajuda para se movimentar, contudo, a presença da materialidade que instiga a bebê 


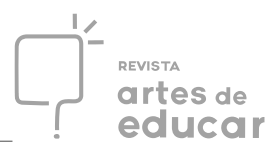

é uma intervenção no espaço que sugere uma provocação à movimentação. Assim, podemos pensar a ideia de entorno óptimo, como configuração de um ambiente aprazível à movimentação do corpo com elementos à volta em uma distância que permita interações, o móbile em uma altura alcançável com cores e textura que convidam ao toque, o espelho, cujo efeito propicia o alcance da visão e a fugacidade do movimento pela percepção da criança. Denota-se que a tendência de Laura era permanecer deitada, sendo a postura de girar o dorso para alcançar o objeto de interesse um desafio para ela, dado que por sua iniciativa pouco se viu tal movimentação quando os objetos se encontravam a certa distância no chão.

\section{Sequência 2: Interação com tecido}
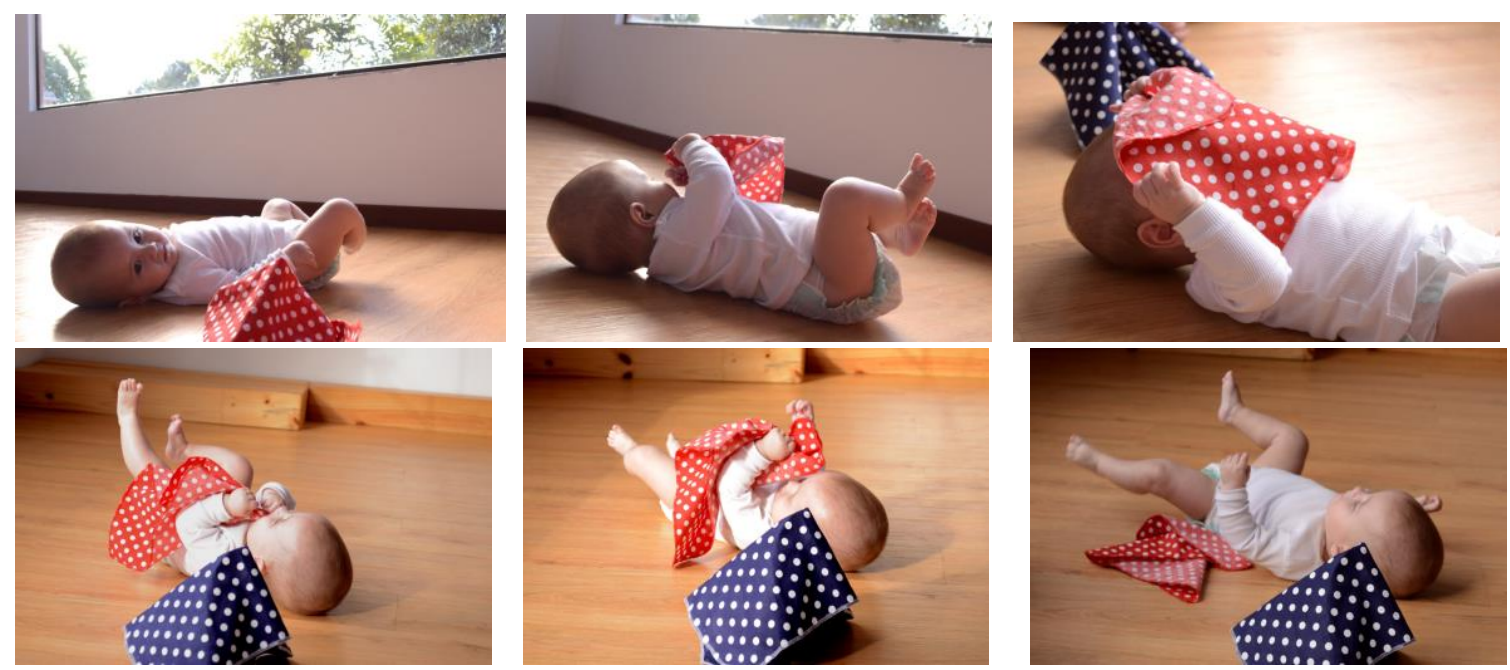

FONTE: Daniele Marques Vieira (2018)

LEGENDA: Situação de Interação, Sala da Turma, criança de 07 meses, Escola Parlenda

Um mês mais velha, já familiarizada ao contexto, tanto em relação aos espaços diferenciados, como às possibilidades interativas conforme os objetos disponibilizados, Laura se mostra mais maleável em sua movimentação, possuindo o objeto-tecido com o gesto de preensão, o traz à boca, cobre a face, manipula em sua direção, assim como, seus membros se movimentam de forma mais livre e intensa, demonstrando maior flexibilidade. Em relação ao conceito de entorno óptimo, destacamos desse ambiente em que está Laura - Sequência 2 -, a Sala de Movimento, uma janela cuja altura permite o alcance da visão da bebê a elementos do ambiente externo e a percepção da luminosidade que dela se expande, o piso de madeira favorável por sua temperatura e textura, o qual lhe possibilita exercer o movimento livre a partir de si, elementos que demarcam sua percepção corporal por sensações e pela potência do próprio corpo; considerando a postura de Laura deitada no chão, o pano vermelho com bolinhas brancas 


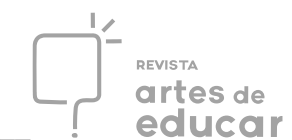

próximo ao seu plano de visão e alcançável, sugere uma intencionalidade da prática educativa a provocar sua movimentação, o que se confirma pela postura da cabeça voltada para o lado demonstrando com o olhar, interesse pelo objeto. As estratégias de movimentação de Laura, como a agitação dos membros, o giro da cabeça, a especialização dos gestos pela manipulação do pano, a ação de cobrir o rosto, são aspectos que caracterizam o seu modo de se relacionar neste espaço-ambiente, cujos elementos que o compõem, indiciam possibilidades interativas e confrontam a bebê com seus interesses, criando espaço à curiosidade e experimentação desde si, por seu ritmo próprio. Ainda que se possa estimar, conforme os parâmetros piklerianos, que entre 4 e 8 meses os bebês podem virar de barriga para baixo, Laura não demonstra tal iniciativa e permanece na posição com o dorso estendido no chão de madeira explorando sua extensão e o jogo da cabeça que se vira em busca dos elementos de interesse, constituindo um equilíbrio à movimentação dos membros.

\section{Sequência 3: Interação com bolas, macarrão e elementos de madeira}
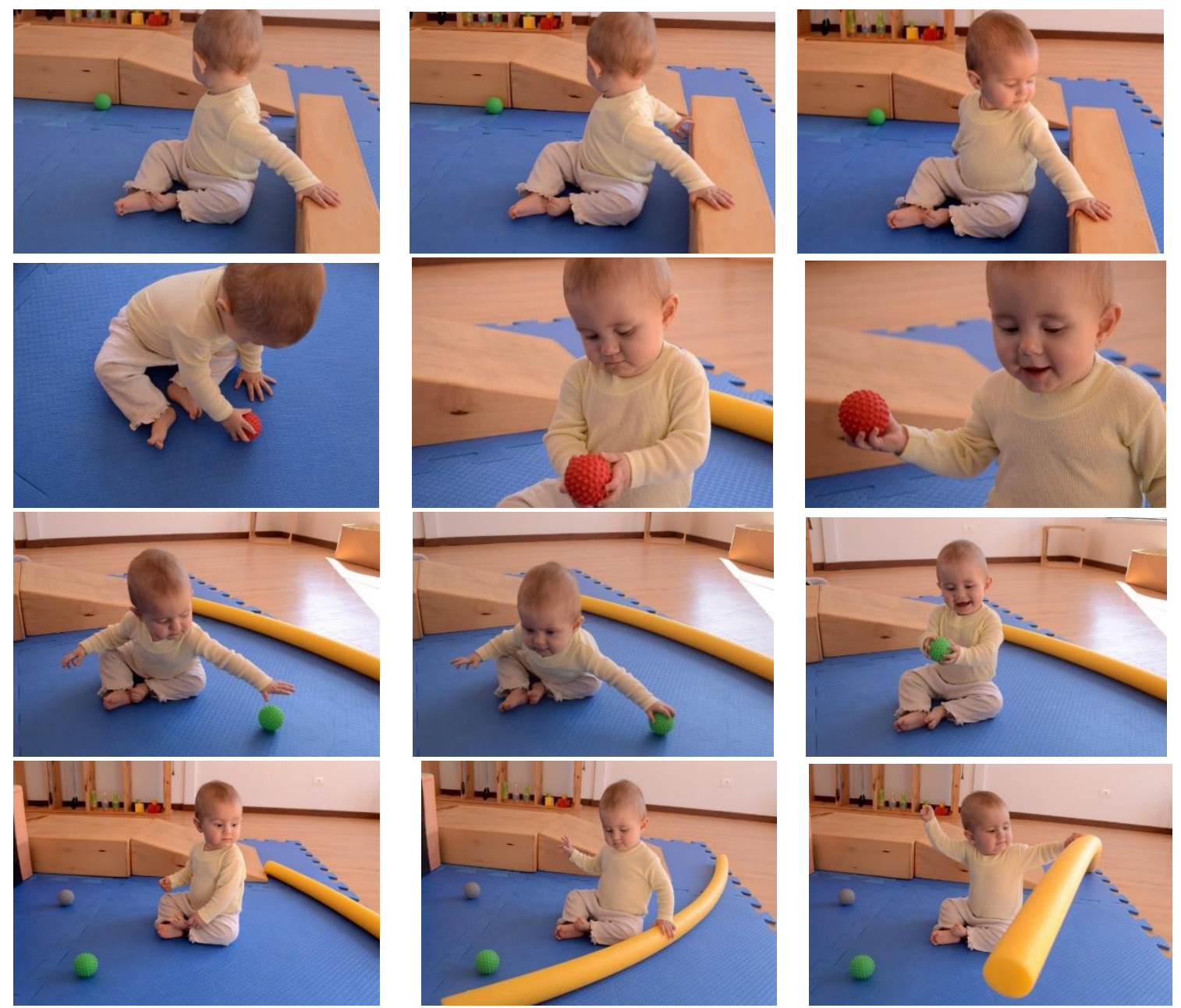

FONTE: Daniele Marques Vieira (2018)

Revista Interinstitucional Artes de Educar. Rio de Janeiro, V. 6, N.2- pág. 602-626 maio-agosto de 2020: "Bebês e crianças: cultura, linguagem e políticas" 
LEGENDA: Situação de Interação, Sala da Turma, criança de 10 meses, Escola Parlenda.

Aos dez meses, Laura demonstra estar confortável na postura sentada, se mostra bastante à vontade nessa posição para girar, alcançar objetos, deslocar-se, denota-se que nesse momento sua movimentação no espaço se dava pelo deslocamento sentada impulsionando os pés, ainda que esta forma fosse incomum aos olhos das professoras, para Laura parecia perfeitamente aceitável e eficaz uma vez que não a impedia de mover-se até onde quisesse. Conforme se observa na Sequência 3, a posição do corpo, a expressividade e as ações realizadas deflagram um equilíbrio em que parece fluir a intencionalidade e a conquista do objeto desejado, o que Laura manifesta em seus balbucios percebidos como vestígios nas imagens. Segundo a Professora 1, mediante o acompanhamento e as observações do movimento livre de Laura, confrontados aos parâmetros piklerianos, percebeu-se que ela não vivenciou com intensidade entre os 7 e 10 meses, as posturas de virar de barriga para baixo, girar repentinamente, deslocar-se rodando, rastejar, colocar-se semisentada (SOARES, 2017, p. 57-58). Na Sala de Movimento, preferencialmente as professoras colocavam Laura deitada para exercer por sua iniciativa estratégias que a levassem a aprimorar sua movimentação, ainda que seu desejo fosse permanecer sentada. Assim, constituído o entorno óptimo com objetos para apoio - elementos móveis de madeira, espumados com formatos diferenciados - e objetos para manipular - bola e espaguetes de espuma -, por vezes, após algum tempo para ela experimentar as materialidades propostas, ao alcançar a postura sentada, toda sua movimentação se centrava nessa posição, como o giro e a flexão do dorso, o alongamento do braço e o uso das mãos para alcançar objetos, o que se evidencia na Sequência 3.

Podemos caracterizar o processo educativo de Laura no ano de 2018, pela conquista do seu entorno a partir de uma movimentação peculiar, movida pela curiosidade diante das propostas oferecidas, em uma atitude de observar os detalhes, explorar os objetos do espaçoambiente, se expressar pelo gesto, olhar e balbucios (Relatos da Professora 1). Destacamos que, ao final do ano, com 14 meses, havia uma percepção de que Laura parecia confortável com sua movimentação, mantendo-se primordialmente sentada.

No ano seguinte, já nas primeiras semanas, Laura demonstra interesse e iniciativa de dar os primeiros passos. Enquanto a maioria das crianças do grupo de Laura já caminhava ou se lançava a deslocamentos entre elementos mediadores - pufs, prateleiras baixas, mesinhas -, impulsionada pelo ímpeto de alcançar a condição de deslocar-se no espaço e interagir por essa nova postura, Laura experimentava esticar as pernas, provando o equilíbrio de permanecer ereta. 


\section{Sequência 4: Interação na sala de movimento}
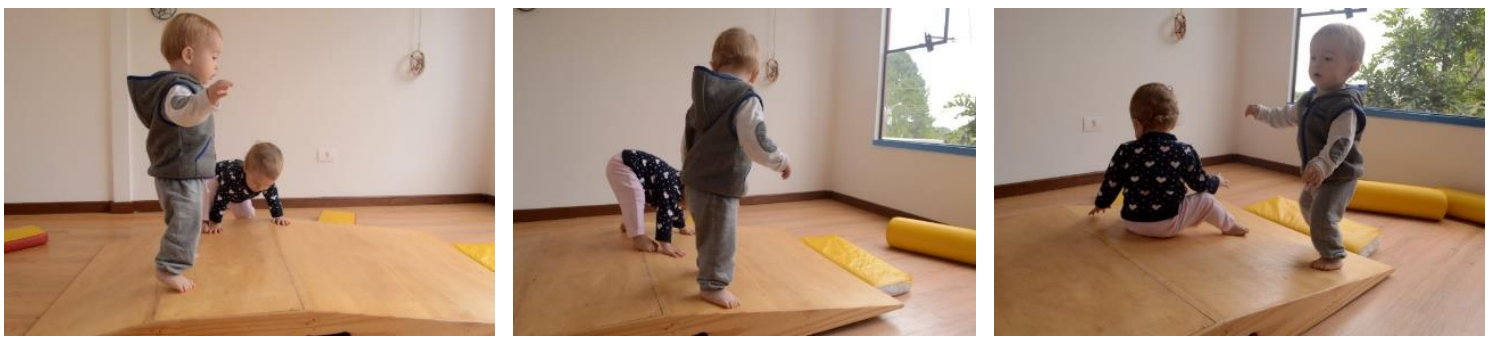

FONTE: Daniele Marques Vieira (2019)

LEGENDA: Situação de Interação, Sala de Movimento, crianças de 14 a 16 meses, Escola Parlenda.

Assim, em interação com Luiz ${ }^{12}$, que nasceu dois meses depois de Laura, na Sala de Movimento ela prova as potencialidades do próprio corpo na exploração do espaço e de elementos conhecidos - a rampa de madeira e os espumados comuns em suas interações na Varanda $^{13}$-, agora a partir de outra perspectiva ocupam posição central nesse espaço. A observação dos movimentos de Luiz e o compartilhamento do espaço e seus objetos, conformando o entorno óptimo, configuram desafios ao mesmo tempo em que se constituem mediadores da movimentação de Laura, e se revelam constituintes da condição de conquista da sua autonomia.

Seja pela composição dos elementos de madeira e de espumados, que denotam estabilidade e facilidade aos deslocamentos dos bebês, seja pela possibilidade desafiadora de movimentação que esses elementos ensejam, a prática educativa se dá pela presença das professoras na organização do espaço e pela atenção a cada movimento realizado capturado também pela pesquisadora que documenta as interações, acompanhando e legitimando os gestos e iniciativas de cada um, dado o modo como ocorre a interação entre os bebês e os adultos e se estabelece uma relação, marcada pela confiança e valorização das ações realizadas pelos bebês. E isso parece também compor-se como condição favorável, posto que eventualmente se mostra evidente quando os bebês olham para o adulto e sorriem mediante ações realizadas, reiterando a relação de interpendência entre eles à constituição da agência dos bebês (PROUT, 2005; WYNESS, 2013). 
Vale ressaltar a autonomia como uma conquista que também se assenta nas condições asseguradas pelas profissionais, não imposta, mas vivida, conquistada, a cada observação, interação, movimento. Conforme o princípio pikleriano do valor da atividade autônoma, que tem como foco a capacidade do bebê de agir por si, constitui uma das condições oferecidas pela prática ao propiciar circunstâncias adequadas para que descubram o prazer que sua própria atividade espontânea pode lhe dar (DAVID; APPELL, 2013, p. 24). Nessa perspectiva, para respeitar a liberdade do bebê em sua movimentação, a intervenção do adulto é indireta e considera: a preparação do espaço-ambiente mediante situações pertinentes ao processo vivido pelo bebê - compondo materiais ao seu alcance em função de seu interesse e possibilidades; o respeito ao ritmo de aquisições motoras de cada bebê - levando em conta suas estratégias e iniciativas; a linguagem, com ênfase na palavra como reconhecimento da conquista pelo bebê que o ajuda a tomar consciência dos seus avanços (DAVID; APPELL, 2013). Ao reconhecer as capacidades dos bebês, o adulto cria condições que legitimam suas ações e favorece que eles possam atribuir, ao seu próprio tempo, sentidos para aquilo que vivenciam e conquistam no cotidiano, se constituindo parceiro privilegiado na significação do mundo pelo bebê (BONDIOLI, 1999).

\section{Sequência 5: Interação com elementos de madeira e espumado}
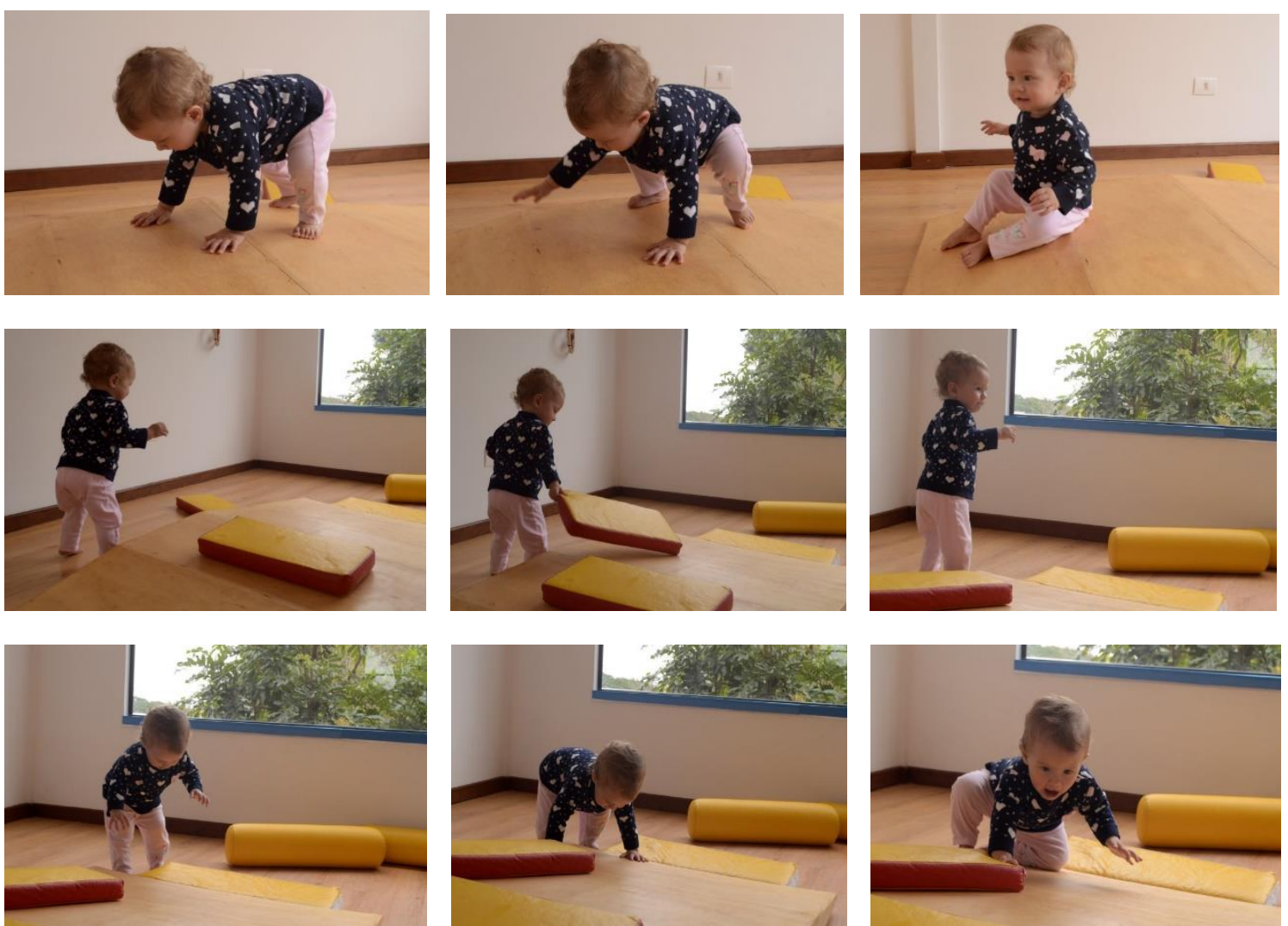

Revista Interinstitucional Artes de Educar. Rio de Janeiro, V. 6, N.2- pág. 602-626 maio-agosto de 2020: "Bebês e crianças: cultura, linguagem e políticas" 

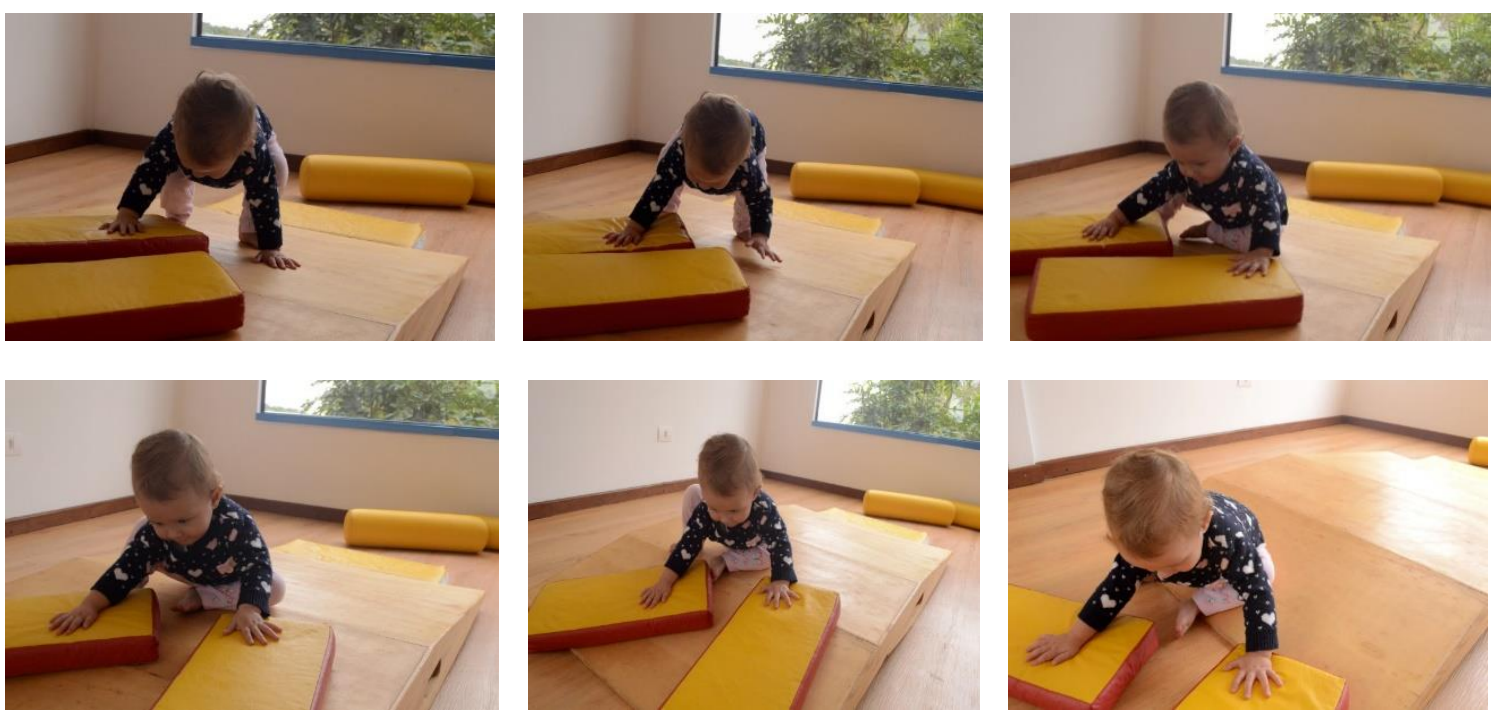

FONTE: Daniele Marques Vieira (2019)

LEGENDA: Situação de Interação, Sala de Movimento, criança de 16 meses, Escola Parlenda.

Na Sequência 5 Laura desloca-se no espaço utilizando a rampa de madeira como elemento de referência enquanto os espumados servem de apoio, constituindo mediadores de seu deslocamento que se transformam em objetos lúdicos para provar as possibilidades corporais e sensações resultantes do equilíbrio que alcança, consigo e na relação com o meio. As ações de Laura reiteram a perspectiva pikleriana sobre a iniciativa do bebê de auto governar-se e de organizar os elementos do espaço segundo sua capacidade de movimentação, mediante um entorno óptimo que lhe favoreça exercer sua autonomia (GODALL, 2016). Nas imagens dessa Sequência 5 se evidenciam as mãos, ora suporte da ação para o equilíbrio que o corpo de Laura alcança, ora gesto que comunica intencionalidade de outra ação - empurrar os espumados -, ao mesmo tempo em que revelam o domínio do próprio corpo nessa situação. Essas evidências que as mãos de Laura sugerem, convidam a pensar as relações do ato ao pensamento pronunciadas por Wallon (2008), em que este autor discorre e diferencia gesto prático e gesto ritual, sendo o gesto sempre a figuração simbólica de um ato. Um - o gesto prático - é inventivo, é guiado por uma espécie de intuição plástica que o leva a experimentar e utilizar as qualidades ou propriedades das coisas (WALLON, 2008, p. 116). Neste caso, ao nos voltarmos para a Sequência 5, podemos relacionar a ação de Laura de posicionar as mãos sobre o espumado e empurrá-los, a sugestão da pressão como uma força que manifesta seu domínio em relação a eles, com a intenção de fazê-los se mover, juntamente com o corpo em equilíbrio, remete à manifestação de sua autonomia. Enquanto, o gesto ritual, pelo contrário, abrindo o indivíduo às influências do meio que lhe fornece seu modelo (WALLON, 2008, p. 116) sugere algo já visto, 


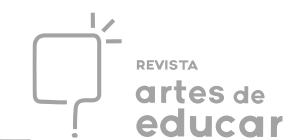

compartilhado e representado, a ser apropriado por Laura em sua ação de mover os espumados e mover-se com eles. Seria essa uma investida lúdica associada ao ato motor, expressão de sua autonomia?

Nesse período de suas conquistas, intensificou-se entre as ações de Laura, colocar-se de pé e provar o controle da postura ereta. O domínio do caminhar e a percepção de deslocamento, pé ante pé, constituem indicativos dessa nova condição que Laura experimenta e se dedica em aprimorar. Voltando a realizar o mesmo percurso estaria em busca por experimentar a mesma sensação de competência e segurança pela conquista da aprendizagem do caminhar?

\section{Sequência 6: Interações com os pares no quintal.}
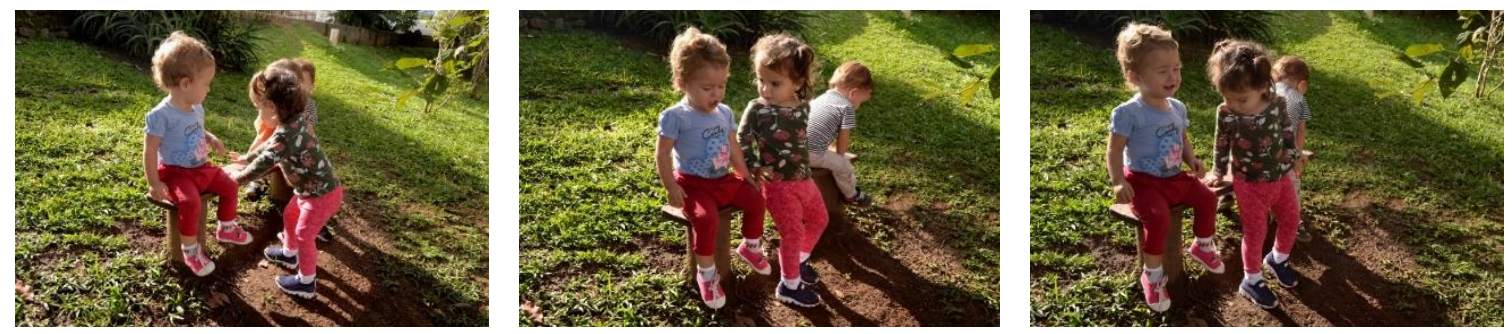

FONTE: Daniele Marques Vieira (2019).

LEGENDA: Interação com pares na natureza, Quintal, crianças de 18 a 20 meses, Escola Parlenda.

Mais experiente com o próprio corpo, nesta Sequência 6, Laura prova a posição sentada em um banco no Quintal, onde outras crianças também se lançam a provar e compartilhar a sensação gerada por suspender-se do chão, de sentir a leveza do corpo, com as pernas soltas, enquanto o dorso em equilíbrio sustenta o corpo todo. Ao acompanhar o entorno, olhar para o chão, a expressão de Laura parece manifestar a satisfação de estar sobre o banco, como uma conquista de si. Nesse momento, já possuidora de um equilíbrio capaz de lhe possibilitar desafios corporais mais amplos, como a interação com o banco sugere, se mostra pertinente as relações entre ato e pensamento, mediante o gesto ritual preconizado por Wallon (2008), em que os pares têm papel crucial à conquista da autonomia, pela possibilidade de sua ação como modelo a ser experimentado, ou antes, uma referência para a experimentação.

\section{Sequência 7: Interações com o ambiente do quintal}



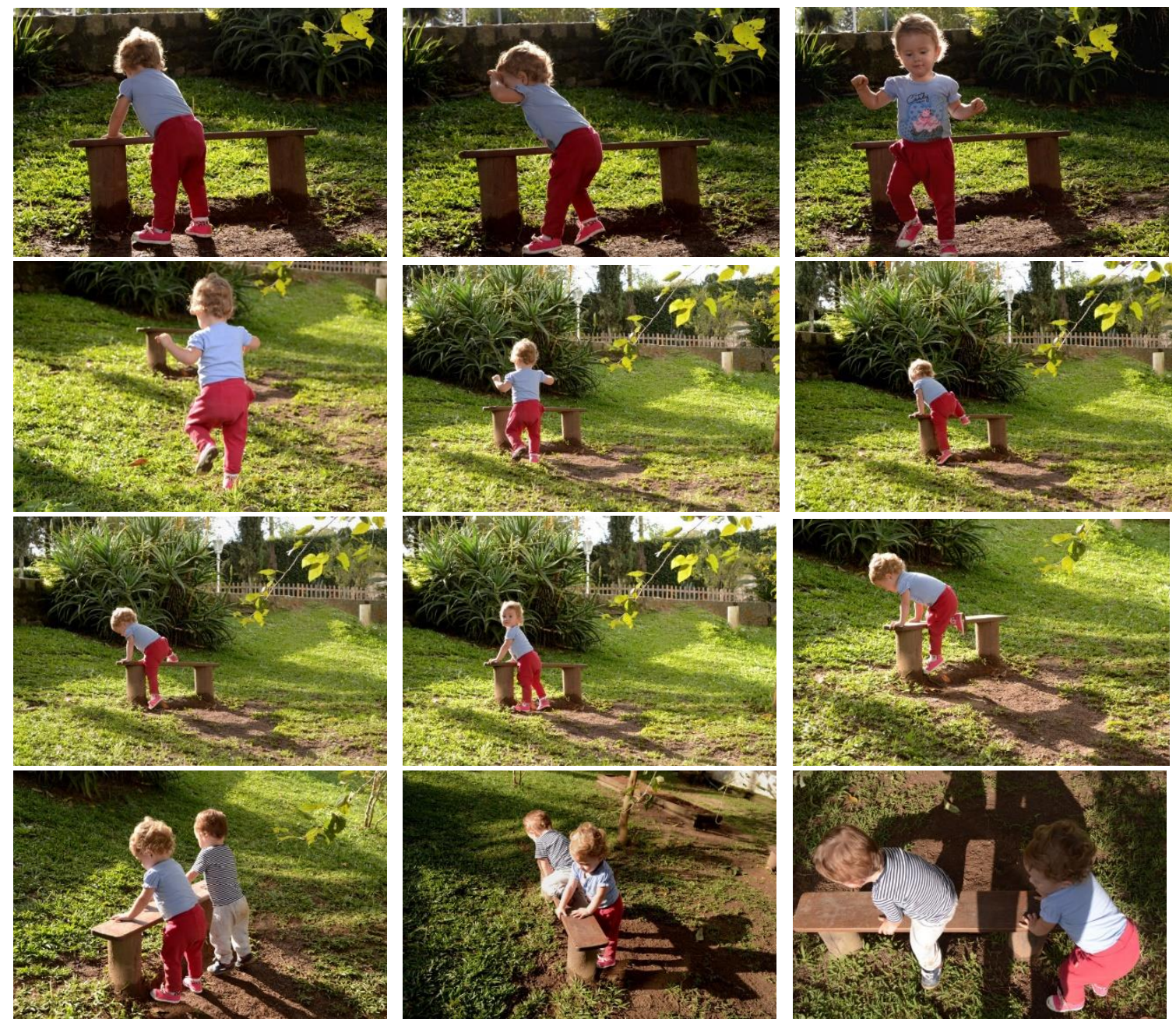

FONTE: Daniele Marques Vieira (2019).

LEGENDA: Interação com pares na natureza, Quintal, crianças de 18 meses, Escola Parlenda.

Como um campo de possibilidades que são intermitentemente provadas, dominadas e cada vez mais dominadas, porque experimentadas repetidas vezes (SARMENTO, 2004), o Quintal se constitui em um entorno óptimo povoado de vida, de encontros e desafios possíveis que Laura decide como provar. Na Sequência 7, vemos seu corpo oscilar enquanto caminha no terreno irregular do gramado em leve declive, ao alcançar outro banco ensaia passar a perna por cima, o gesto que enseja um movimento conhecido e almejado se configura como algo compartilhado com os pares, compondo um repertório de possibilidades a serem experimentadas, ao seu próprio tempo, assim como sugere a vinda de Fernando ${ }^{14}$ que alça a perna, alcança o equilíbrio e senta-se no banco, enquanto Laura observa e acompanha seu movimento. Ainda que não efetive a mesma ação de Fernando, as imagens indicam a visualização do gesto ritual como repertório de sua vivência no Quintal. Em sua postura e expressão se denotam a escolha e certa 
satisfação com o alcançado, seria o próprio banco objeto de seu desejo, uma possibilidade a ser experimentada ao seu tempo?

\section{Sequência 8: Colocar o calçado}
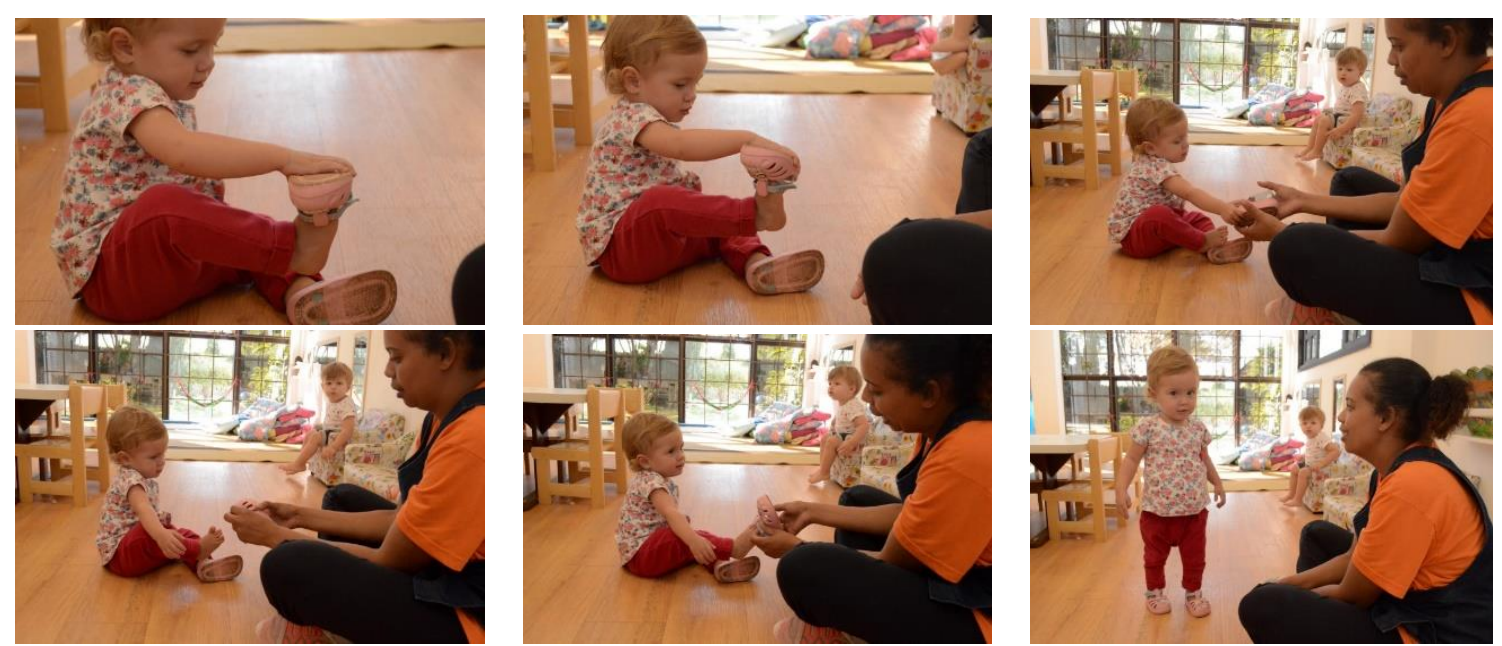

FONTE: Daniele Marques Vieira (2019).

LEGENDA: Colocar o calçado com ajuda da professora, Praça, criança de 19 meses, Escola Parlenda.

As vivências oportunizadas neste novo grupo frequentado por Laura, após um ano de convivência no contexto educativo, com dinâmicas de organização, construção de práticas culturais próprias à experiência na creche, formas de ocupação e interação em ambientes diferenciados, bem como a possibilidade de constituir referências a modos próprios aos bebês de agir sobre o meio, em suas relações e em prol de seus interesses e necessidades, remetem à sua condição social, de sujeito que se constitui na relação com outros sujeitos por meio da cultura. Essa compreensão coaduna com a perspectiva defendida por Prout (2010) no âmbito dos novos estudos da infância, que não cabe separar natureza e cultura, pois em uma visão dicotômica, o processo de socialização das crianças se caracterizaria por sair de uma condição de natureza (criança pequena) para uma condição social (adulto). Para o autor o caráter híbrido da infância, em parte natural e em parte social, parece claramente incômodo para a mentalidade moderna, com sua preocupação em dicotomizar os fenômenos (PROUT, 2010, p. 736), o que permitiu ao campo avançar na compreensão da necessidade de incluir o terceiro excluído, natureza e cultura são dimensões presentes no processo de tornar-se humano, o que implica a conquista da autonomia, e não devem ser tidos como opostos.

Podemos ainda relacionar a conquista da autonomia à constituição do gesto ritual como apropriação do bebê mediante as oportunidades vividas na creche, explicitadas nesta instituição como rituais compartilhados pelo grupo ${ }^{15}$, tais como as ações de preparação para vivências em 
ambientes diferenciados: tirar o calçado para entrar na Sala de Movimento; colocar o calçado apropriado para vivências no Quintal onde há irregularidades; trocar o calçado para permanecer na Praça.

Nessa Sequência 8, em que Laura aparece com a Professora 2, podemos referir ao gesto ritual como a ação em foco. Interessada por seus pertences, em dominar as ações de cuidado de si, Laura demonstra sua capacidade de manipular os objetos, tentando colocar o calçado no pé, coordena o gesto e a postura para alcançar êxito, experimenta a posição, e solicita à professora ajuda com sua intenção de calçar-se. Finalizada a ação conjunta, volta-se à pesquisadoradocumentarista e demonstra satisfação com sua condição de estar calçada. A sequência de ações e expressões visíveis nessa narrativa, remetem ao princípio pikleriano do valor da atividade autônoma quanto à postura de Laura em sua iniciativa de colocar o calçado, por outro lado, também referem o princípio de atenção pessoal, cujo adulto lança mão ao acompanhar e interagir com a criança mostrando-se disponível ao seu chamado e solicitação de ajuda, reiterando a intervenção indireta enfatizada por David e Appell (2013), assim como o conceito de agência do bebê sob uma relação de interdependência com o adulto (WYNESS, 2013).

Em sua trajetória de bebê, desde que chegou à instituição educativa, Laura demonstrou interesse pelo entorno, primeiro dominando o gesto, ao manipular objetos exercendo a preensão, na comunicação com o outro o olhar e os balbucios logo preencheram de significados as relações, para então, dedicar-se corporalmente em seu deslocamento. Atenta e curiosa aos detalhes, muitas vezes, Laura mantinha-se envolvida com pequenos objetos, o que lhe permitiu dominar as experimentações pelos gestos minuciosos. Interessada por brincadeiras que envolvem tecidos, explora as transparências, formas e texturas e brinca também de se esconder. Sempre que está disponível, o tecido é um elemento escolhido para compor suas brincadeiras (Professora 2). Essa observação das escolhas de Laura sobre o potencial do tecido como objeto de interação, revela seu conhecimento sobre algo que ela viveu, também referenciada pela Professora 1 em seu primeiro ano de creche, o que aprimorou como peculiaridade do seu modo de se apropriar do mundo, revestindo suas ações manifestadas em suas escolhas. Portanto, aquilo que caracteriza os processos vivenciados pelos bebês tem uma relação direta com seus interesses e seus modos de inserção no mundo, o que também influenciará suas aquisições e conquistas.

De certo modo, a atenção dispensada por Laura aos detalhes, por sentir e dominar as características dos objetos, lhe permitiu aprimorar sua capacidade de, exercendo o gesto, dominar o objeto de desejo e ao realizar repetidas vezes a mesma ação, investindo na exploração de possibilidades, também experimentar estratégias à conquista de colocar sozinha seu calçado. 


\section{Sequência 9: Colocar a galocha sozinha}
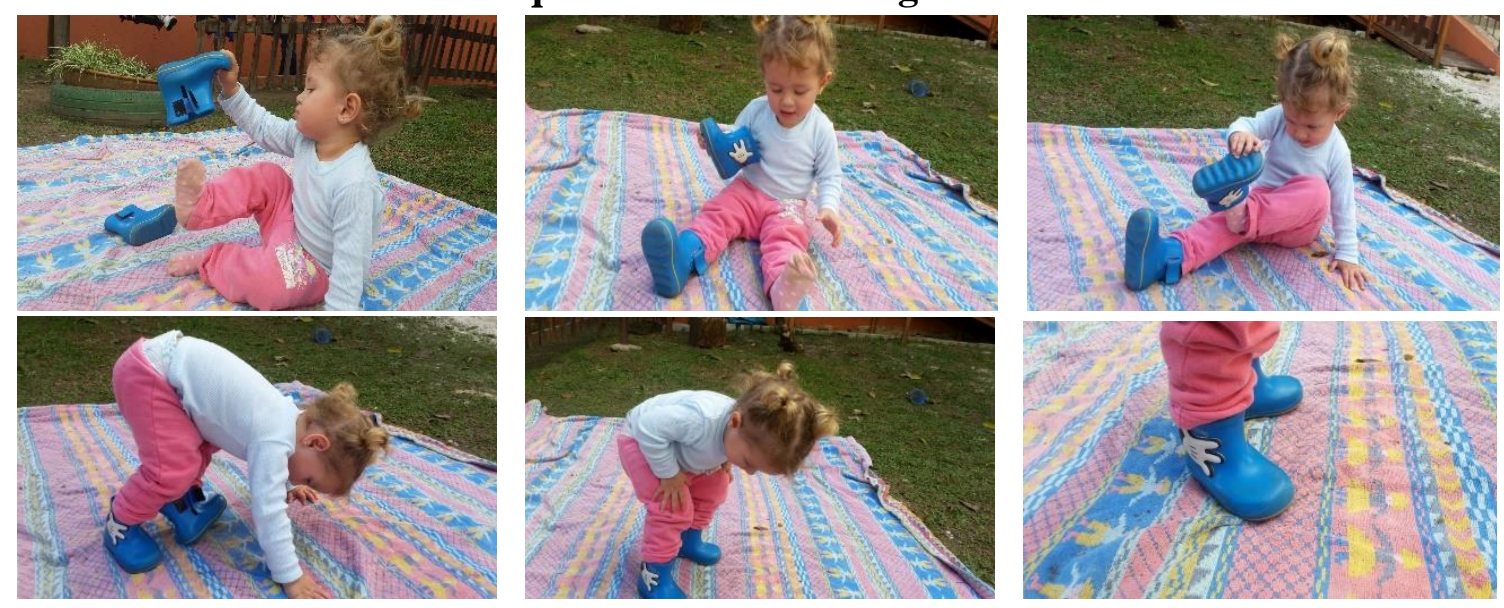

FONTE: Elaine Taborda (2019).

LEGENDA: Colocando a galocha, Quintal, criança de 20 meses, Escola Parlenda.

A construção da autonomia por Laura, como processo vivido e culminando seu segundo ano de vida, foi representada nessa Sequência 9 pela Professora 2 e constitui uma documentação eleita para socializar suas conquistas. Assim, podemos observar nessa sequência de gestos realizados por Laura, a intenção de colocar sozinha sua galocha, a cada gesto e na conclusão dessa ação de calçar-se, ela parece comprovar cada feito e ao final, mediante ajustes e domínio de si, concretiza sua intencionalidade. Nesse sentido, podemos remeter ao princípio pikleriano de valor da atividade autônoma que orienta a prática, pois, para que sua atividade adquira significado, ela sempre deve nascer da própria iniciativa da criança, em uma espécie de automotivação constantemente reforçada pelo resultado obtido (DAVID; APPELL, 2013, p. 24).

Contudo, como experiência educativa, a autonomia também se revela uma construção permeada de significados construídos na relação com o meio sociocultural, especialmente pelas oportunidades oferecidas no contexto da creche por possibilidades interativas que reconhecem a capacidade dos bebês de agir com competência. Se por um lado, podemos constatar o papel do adulto como parceiro privilegiado e que participa na significação do mundo pelo bebê (BONDIOLI, 1999), por outro lado o fato desse adulto acreditar na capacidade do bebê de agir com competência na construção de sua autonomia nos coloca como questão também sua disponibilidade para favorecer o bebê a se tornar independente, neste caso, ser capaz de agir por si mesmo sem necessitar a ajuda. O que sugere indícios de sua emancipação na constituição dos cuidados de si, que só ocorre porque o bebê, sujeito até pouco tempo visto como dependente do adulto, é tomado como alguém que se desenvolve em relação com o seu entorno e que tem 


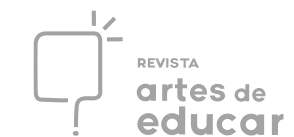

direito a espaços e tempos que promovam a sua ação, e pela compreensão desse como um critério que promove a igualdade entre os diferentes bebês, mas reconhece a diferença que marca os processos na medida em que situa a experiência de cada bebê a partir do seu percurso, dos seus interesses e modos de envolvimento.

\section{ALGUMAS CONSIDERAÇÕES PARA FINALIZAR}

As sequências apresentadas no texto buscam narrar visualmente o processo de conquista da autonomia vivenciado por uma bebê em um dado contexto, com o objetivo de apresentar uma perspectiva de educação que toma o bebê como um ator social competente, e a partir dessa ideia cria condições para que essa competência encontre respaldo para o seu desenvolvimento, e endossa a defesa de uma educação para a emancipação e não para a submissão.

A concepção de entorno óptimo de Godall (2016), como condição fulcral, que não desconsidera a ação do bebê no seu processo de conquista da autonomia, nos permite avançar na compreensão de como a autonomia, ideia tão convocada nos projetos educacionais, pode se constituir em uma prática que respeita os ritmos dos bebês, não impõe a eles atividades que devem fazer sozinhos porque, supostamente, já são capazes. Em outra direção, a autonomia se sustenta como um princípio que orienta a ação adulta na mediação da liberdade de ação das crianças, de modo singular, e pautada na observação atenta, cuidadosa e sistemática das vivências infantis.

Nessa lógica, não se trata de submeter as crianças a normas sociais baseadas em valores morais, mas a criar espaços e tempos de vivências interativas que permitam que as crianças, desde bebês, signifiquem os espaços, os tempos, o seu corpo, os seus movimentos, as interações com o outro, de modo a sentirem-se provocadas a fazer descobertas. Nessa perspectiva um elemento central vinculado ao papel das profissionais é a sua capacidade de instigar a curiosidade dos bebês, como inquietação indagadora conforme destaca Freire (2002, p. 22) não haveria criatividade sem a curiosidade que nos move e que nos põe pacientemente impacientes diante do mundo que não fizemos, acrescentando a ele algo que fazemos. Assim parece a criança, ser de infinitas possibilidades, que ao tatear o mundo, com ele vai-se fazendo.

Outro aspecto relevante na abordagem sobre a conquista da autonomia é a problematização de uma ideia universal de desenvolvimento das crianças. Neste sentido, tomamos como referência em nossas análises a Escala de Desenvolvimento Infantil do Instituto 


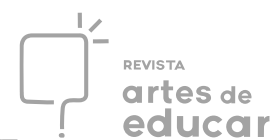

Emmi Pikler para o desenvolvimento motor, a escala prevê a conquista de determinados movimentos pelas crianças ao longo dos seus primeiros anos de vida, definição que pudemos confrontar com o processo de Laura, no sentido de demarcar que embora tenhamos alguma previsibilidade nos processos de desenvolvimento, o que nos permite fazer escolhas no âmbito pedagógico, cada processo é singular, as crianças possuem ritmos próprios, interesses, histórias de vida com referentes culturais, também incidem nas escolhas das professoras.

Essa assertiva ganha adensamento com as narrativas visuais, que permitem uma análise profunda e sistemática dos processos vivenciados por cada criança e são materiais extremamente ricos para a formação das professoras, tanto das que vivenciam a prática da documentação no seu cotidiano de trabalho, quanto àquelas que ainda lutam por condições propicias para que essa prática possa se efetivar. Documentar, na perspectiva aqui defendida, tem algumas exigências, como a possibilidade de observar atenta e sistematicamente pequenos grupos de crianças, o que permite olhar e identificar detalhes, ter tempo para organizar os materiais e discuti-los coletivamente, planejar o processo de documentação a fim de perseguir situações que permitam repertoriar sobre as experiências vividas por cada criança no contexto da creche, tomar consciência da constituição da docência por meio do exercício intelectual de pensar sobre o fazer do bebê.

Assim, acompanhar o processo de Laura é uma oportunidade para refletirmos sobre o que implica a conquista da autonomia, não apenas na experiência de tornar-se criança da própria bebê, mas nos inúmeros aspectos que compõem a vida em um espaço coletivo de educação e cuidado, tanto para os bebês quanto para as professoras que partilham essa experiência com eles, para respondermos ao compromisso, como defende Batista (2008), da educação infantil como um lugar de emergência da infância.

\section{REFERÊNCIAS}

BATISTA, R. Cotidiano da Educação Infantil: Espaço Acolhedor de Emancipação das Crianças. Revista Zero-a-Seis, volume 10, número 18, 2008, p. 53-67. Disponível em: https://periodicos.ufsc.br/index.php/zeroseis/article/view/1980-4512.2008n18p53/8077 Acesso em: outubro de 2012.

BONDIOLI, A. A dimensão lúdica da criança de 0 a 3 anos na creche. In: BONDIOLI, A.; MANTOVANI, S. Manual de Educação Infantil: de 0 a 3 anos - uma abordagem reflexiva. $9^{a}$ ed. Porto Alegre, ArtMed, 1998, p. 212-227. 
BRASIL. Conselho Nacional de Educação. Câmara da Educação Básica. Resolução CNE/CEB n. 05, de 28 de maio de 2009. Fixa as Diretrizes Curriculares Nacionais para a Educação Infantil. Brasília, 2009.

COUTINHO, A. S. A ação social dos bebês a partir da teoria compreensiva de Max Weber. In: TEBET, G. (org.). Estudos de bebês e diálogos com a sociologia. São Carlos: Pedro \& João Editores, 2019, p. 49-64.

A ação social dos bebês: um estudo etnográfico no contexto da creche. Tese (Doutorado em Estudos da Criança). Braga: Programa de Pós- -Graduação em Estudos da Criança, Universidade do Minho, 2010.

COUTINHO, A. S.; MORO, C.; VIEIRA, D. M. A avaliação da qualidade da brincadeira na educação infantil. Cadernos de Pesquisa, São Paulo, v. 49, n. 174, p. 52-74, out./dez. 2019.

DAVID, M; APPELL, G. Lóczy, una insólita atención personal. 3. ed. Barcelona: OctaedroRosa Sensat, 2013.

FREIRE, P. Pedagogia da Autonomia. 25 ed. Rio de Janeiro: Paz e Terra, 2002.

GRAMSCI, A. Escritos políticos: (1910 - 1920). Rio de Janeiro: Civilização Brasileira, 2004.

GODALL, T. C. Vida cotidiana y transformaciones silenciosas. Revista Aula Infantil. n. 76, Logroño, España: Universidad de la Rioja: Ediciones Graó, 2014, p. 11-16.

GODALL, T. C. Movimiento Libre y entornos óptimos. Reflexiones a partir de estudios con bebés. RELAdEI, 5.3, Monográfico Pikler-Lóczy, septiembre 2016, p. 79-90.

GONÇALVES, F. A educação de bebês e crianças pequenas no contexto da creche: uma análise da produção científica recente. Dissertação (Mestrado em Educação). Florianópolis: Programa de Pós-Graduação em Educação, Universidade Federal de Santa Catarina, 2014.

GUIMARÃES, D. Relações entre bebês e adultos na creche: o cuidado como ética. Rio de Janeiro: Cortez, 2011.

MANFREDINI, A. L; VIEIRA, D. M. A prática docente na creche: relações entre cuidado ético, educação e experiência. In: DORNELLES, L. V.; LIMA, P. de M. (Orgs.). Por uma luta em defesa dos direitos das crianças: corpo e cultura [livro eletrônico]. Vol. I. Goiânia: Editora Vieira, 2019, p. 91-103.

MATTOS, M. N. de S. S. de. Bebês e livros: relação, sutileza, reciprocidade e vínculo. Tese (Doutorado em Educação). Programa de Pós-graduação em Educação. Rio de Janeiro: Pontifícia Universidade Católica do Rio de Janeiro, 2018.

MORO, C.; VIEIRA, D. M. Como podemos apresentar a literatura no cotidiano dos grupos de bebês. In: MORO, C.; SOUZA, G. de (orgs.). Educação infantil: construção de sentidos e formação. 1. ed. Curitiba: Editora UFPR, 2019, v. I, p. 173-194.

Revista Interinstitucional Artes de Educar. Rio de Janeiro, V. 6, N.2- pág. 602-626 maio-agosto de 2020: "Bebês e crianças: cultura, linguagem e políticas" 
NEYRAND, G. L'enfant, la mère et la question du père. Un bilan critique de l'évolution des savoirs sur la petite enfance. $2^{\mathrm{a}}$ ed. Paris, França: Presses Universitaires de France, 2000.

PROUT, A. The future of childhood. Towards the interdisciplinary Study of children. London: Routledge Falmer, 2005.

. Reconsiderando a nova sociologia da infância. Cadernos de Pesquisa, v. 40, n. 141, p. 729-750, set./dez. 2010. Disponível em: http://www.scielo.br/pdf/cp/v40n141/v40n141a04.pdf Acesso em: 12 de novembro de 2015.

ROCHA, E. A. C. A pesquisa em educação infantil. Trajetória recente e perspectiva de consolidação de uma Pedagogia da Educação Infantil. Florianópolis: UFSC, CED, NUP, 1999.

SARMENTO, M. J. As Culturas da infância nas encruzilhadas da segunda modernidade. In: SARMENTO, M. J.; CERISARA, A. Be. Crianças e miúdos: perspectivas sociopedagógicas da infância e educação. Porto: Asa, 2004, p. 9-34.

SOARES, S. M. Vínculo, movimento e autonomia: educação até 3 anos. São Paulo: Omnisciência, 2017.

TEBET, G. G. de C. Isto não é uma criança! Teorias e métodos para o estudo dos bebês nas distintas abordagens da Sociologia da Infância de língua inglesa. Tese (Doutorado em Educação). Programa de Pós-graduação em Educação. São Carlos: Universidade de São Carlos, 2013.

VIEIRA, D. M. Imagens benjaminianas para pensar relações entre infância, educação de crianças pequenas e natureza. Revista Contrapontos. Itajaí, out/dez, v. 18, n. 4, p. 374-389, 2018.

Disponível em: https://siaiap32.univali.br/seer/index.php/rc/article/view/13221. Acesso em: 12 set. 2019a.

VIEIRA, D. M. A fotografia na experiência educativa de professores: do olhar e das interpretações. Educ. rev. [online]. 2019, vol.35, n.74, p.309-327. Disponível em: http://dx.doi.org/10.1590/0104-4060.63667. Acesso em: 28 set. 2019b.

VIEIRA, D. M.; COUTINHO, A. S. A ação social dos bebês, as narrativas visuais e a constituição da docência. Poiésis. [online]. 2019a. Unisul, Tubarão, jul/dez, v. 13, n. 24, p. 256275.

VIEIRA, D. M.; COUTINHO, A. S. As narrativas visuais na educação infantil: diálogos entre pesquisa, formação docente e experiência educativa. In: DORNELLES, L. V.; LIMA, P. de M. (Orgs.). Por uma luta em defesa dos direitos das crianças: corpo e cultura [livro eletrônico]. Vol. I. Goiânia: Editora Vieira, 2019b, p. 495-506.

WALLON, H. Do ato ao pensamento: ensaio de psicologia comparada. Petrópolis, RJ: Vozes, 2008.

WYNESS, M. Children's participations and interfenerational dialogue: bringing adults back into the analysis. In: Childhood, october, 2012, p. 1-14. Disponível em: http://chd.sagepub.com/ Acesso em 25 de julho de 2013.

Revista Interinstitucional Artes de Educar. Rio de Janeiro, V. 6, N.2- pág. 602-626 maio-agosto de 2020: "Bebês e crianças: cultura, linguagem e políticas" 
i Doutora em Estudos da Criança, especialidade em Sociologia da Infância. Professora adjunta na Universidade Federal do Paraná, Departamento de Teoria e Prática de Ensino e Programa de Pós-Graduação em Educação do Setor de Educação, pela Linha de Pesquisa Diversidade, Diferença e Desigualdade Social em Educação e ainda, integra o Núcleo de Estudos e Pesquisa em Infância e Educação Infantil (NEPIE), da Universidade Federal do Paraná (UFPR), campus Rebouças, Curitiba/PR, Brasil. E-mail: angelamscoutinho@ gmail.com. ORCID http://orcid.org/0000-0002-3709-8561.

ii Doutora em Educação, atua como consultora em Educação Infantil, integra o Núcleo de Estudos e Pesquisa em Infância e Educação Infantil (NEPIE) da Universidade Federal do Paraná (UFPR), campus Rebouças, Curitiba/PR, Brasil. E-mail: danielemarquesvieira@ gmail.com. ORCID http://orcid.org/0000-0001-6866-7053.

${ }^{3}$ A denominação creche se refere ao segmento que compõe a educação infantil brasileira e que abarca a faixa etária em foco neste estudo.

${ }^{4}$ A esse respeito ver: VIEIRA (2019a; 2019b); MANFREDINI; VIEIRA (2019) e VIEIRA; COUTINHO (2019a; 2019b).

${ }^{5}$ Para o autor a reprodução da vida material ocorre nas determinações que compõem a totalidade, sendo a sua defesa que a educação deveria possibilitar que as crianças mais pobres saíssem dessa situação por meio de uma escola única, que promove a emancipação dos alunos.

${ }^{6}$ Constitui campo de outras investigações das pesquisadoras - tanto em relação a processos formativos, no âmbito da formação continuada e pelo acompanhamento de estágio, como acerca de temas intrínsecos à educação infantil se configurando em contexto propício para o aprofundamento de aspectos já abordados em outros textos produzidos ao longo de um período de dois anos e publicados recentemente, para tanto ver: COUTINHO; MORO; VIEIRA, 2019; MANFREDINI; VIEIRA, 2019; MORO; VIEIRA, 2019; VIEIRA; COUTINHO, 2019a; VIEIRA; COUTINHO, 2019b; VIEIRA, 2019a; VIEIRA, 2019b.

${ }^{7}$ Ressalva-se que uma das pesquisadoras assumiu o papel de pesquisadora-documentarista, a escolha foi decorrente do fato de ela ocupar a função de coordenadora pedagógica do berçário na referida instituição durante um período desta investigação (2017-2018), o que favoreceu acompanhar o processo vivido pela bebê cotidianamente em 2018 e pontualmente em 2019, quando assumiu apenas a condição de pesquisadora-documentarista.

${ }^{8}$ Ver VIEIRA, 2019.

${ }^{9}$ Nome fictício para preservar a privacidade da bebê, mediante a autorização da família sobre o uso da imagem e dados relativos ao seu processo educativo.

${ }^{10}$ Espaço diferenciado pela amplitude, janelas baixas com visibilidade do entorno da instituição, piso de madeira e elementos de madeira de inspiração pikleriana, ocupados por pequenos grupos de bebês, para que os adultos possam acompanhar, monitorar e se relacionar com os bebês conforme suas demandas.

${ }^{11}$ Instrumento elaborado pela equipe de pesquisadoras do Instituto Emmi Pikler, para auxiliar as professoras na observação do comportamento das crianças em uma situação controlada, tendo em conta o tempo em que as habilidades são adquiridas e as diferenças de ritmo em entre as crianças (SOARES, 2017).

${ }^{12}$ Nome fictício para preservar a privacidade do bebê.

${ }^{13}$ Espaço amplo com portas de vidro, onde os bebês interagem com propostas e elementos diversos, com foco na convivência em seus grupos de referência ou pequenos grupos, geralmente, no início e final do dia. A ocupação desse espaço-ambiente se diferencia da Sala de Movimento, sendo esta demarcada pela intencionalidade declarada configuração dos elementos eleitos -, a composição dos pequenos grupos e a atenção do adulto direcionada a acompanhar processos de experimentação e conquista de cada criança.

${ }^{14}$ Nome fictício do irmão de Laura.

${ }^{15}$ Dentre esses rituais, se destacam: 1. Preparação para ir ao Quintal - passar repelente e protetor solar, trocar o calçado; 2. Beber água - ao convite para tomar água, as crianças são lembradas de se sentar para segurar os copos com segurança.

Revista Interinstitucional Artes de Educar. Rio de Janeiro, V. 6, N.2- pág. 602-626 maio-agosto de 2020: "Bebês e crianças: cultura, linguagem e políticas"

DOI: 10.12957/riae.2020.46715 